Agro-Science Journal of Tropical Agriculture, Food, Environment and Extension Volume 17 Number 3 (September 2018) pp. 40-45

ISSN 1119-7455

\title{
EVALUATION OF TRAPS AND ATTRACTANTS FOR MASS TRAPPING OF AFRICAN INVADER FLY, Bactrocera invadens ON MANGO IN SOUTH WEST NIGERIA
}

\author{
${ }^{* 1}$ Ugwu J.A., ${ }^{2}$ Omoloye A.A. and ${ }^{3}$ Ogunfumilayo A.O. \\ ${ }^{1}$ Federal College of Forestry, Ibadan, Forestry Research Institute of Nigeria, \\ PMB 5087, Jericho, Ibadan. Oyo State, Nigeria \\ ${ }^{2}$ Department of Crop Protection \& Environmental Biology, University of Ibadan, Nigeria \\ ${ }^{3}$ Nigerian Agricultural Quarantine Services, Federal Ministry of Agricultural \& Water Resources, \\ Moor Plantation, PMB 5872 Ibadan, Nigeria \\ *Corresponding author’s email: dr.amaka2013@gmail.com
}

\begin{abstract}
Mass trapping has demonstrated to be a powerful tool in the control of fruit flies, its use in African countries has currently increased remarkably as a control method. This study evaluated the efficacy of two traps; Lynfield Trap (LT) and Modified Lynfield Trap(MLT) and two lures (Methyl Eugenol (ME) and Protein Bait from Brewery Waste $(P B B W)$ ) for mass trapping of Bactrocera invadens Drew, Tsuruta, \& White (Diptera: Tephritidae) on mango during 2014 and 2015 fruiting seasons. Traps containing attractants were randomly set on mango homestead trees in three replicates at three selected locations in Ibadan Southwest Nigeria. Results showed no significant difference $(p>0.01)$ between the trap types baited with ME attractant, although the MLT recorded higher catches of B. invadens during the two seasons. Methyl eugenol was significantly $(p<0.01)$ more effective than hydrolyzed protein bait from brewery waste in mass trapping $B$. invadens in the three locations of study. However, ME trapped only male $B$ invadens while PBBW trapped both male and female. B. invadens population was highest at the peak of mango ripening (June) and the density of flies trapped in 2015 was significantly $(p<0.05)$ higher than 2014 in all the locations. Suitable choice of traps, lures and season enhances the mass trapping results. The use of Protein bait from brewery waste and modified lynfield trap for monitoring B. invadens and population suppression is promising and should be encouraged since they attract both sexes and less cost effective.
\end{abstract}

Key words: trapping, mango, lures, fruit fly, control

\section{INTRODUCTION}

The African invader fly, Bactrocera invadens, Drew, Tsuruta, \& White (Diptera: Tephritidae) is a quarantine pest of Asian origin infesting several commercial fruit crops (Drew et al., 2005). Bactrocera invadens was first discovered in Kenya in 2003 and later spread to other African countries. In Africa it has been reported from Benin, Cameroun, Democratic Republic of Congo, Ethiopia, Gabon, Ghana, Guinea, Kenya, Togo, Mali, Nigeria, Senegal, Sudan, and Uganda (Drew et al., 2005; Ekesi and Billah, 2007). Bactrocera invadens was first reported in Nigeria in 2005 (CABI/EPPO, 2008; Umeh et al., 2008; Vayssières et al., 2008; Asawalam and Nwachukwu, 2011; EPPO, 2014).

Since the introduction of $B$. invadens into Africa, they have been ravaging many fruits and vegetables that have led to increase in yield losses. $B$. invadens is highly polyphagous and have been confirmed to have a broad host range. It has been reared from mango, lemon, orange, tomato, banana, guava, marula, custard apple, Indian almond, and papaya, among other hosts (Ekesi and Billah, 2007; Rwomushana et al., 2008). Ekesi et al. (2006) reported that mango appears to be the primary host plant. According to report by ICIPE (2007) mango is the second most important tropical fruit traded internationally across the globe. World production of mango in 2005 was estimated at 28.51 million tonnes (Mt) (Evans, 2008). Of this, Africa produced only 2.5 million tones, accounting for about $10 \%$ of fresh fruits and $11 \%$ of processed mango.

Nigeria ranks the 9th position among the ten leading mango producing countries of the world, but does not feature among the ten leading mango fruit exporters due to quarantine restriction (FAOSTAT, 2007). Most of the mango fruits produced in Nigeria are consumed locally as fresh 
fruit and the bulk of fruits marketed in Nigeria are produced by smallholder farmers (Aiyelaagbe et al., 1999; Umeh et al., 2002). The majority of these farmers are not acquainted with efficient fruit fly control options, hence, mango production in Nigeria is currently being constrained by the attack of $B$. invadens.

Current control measures against fruit flies mainly incorporate the use of insecticides as a cover spray or bait and targeting the adult flies (Raga and Sato, 2006). The use of insecticide is not a suitable control measure once the female fly has deposited egg inside the fruit meso carp, because the chances of affecting the larvae inside the fruits is very slim (Moreno et al., 1994). Mass trapping method represents a preventive control measure, which is based on attracting and killing of fruit fly adults, before they get to the fruit to make infestation. The key advantage of mass trapping method is exclusion of fruits and whole canopy contamination by insecticides. The mass trapping methods can be applied by traps of different constructions, which have to be set on the tree canopy. The traps are filled with different types of attractants and treated by insecticide, or they could be filled with attractant-insecticide water solution (Haniotakis et al., 1983; Barcley and Haniotakis, 1991; Bjeliš, 2006). Mass trapping has been reported to show better efficacy over bait sprays and it has lower cost of application especially human labour (Brumas and Haniotakis, 1987; Bumas et al., 1998; Delrio and Lentini, 1993; Bjeliš, 2006.)

Traps designs, including different colors and shapes, are essential to obtain a high efficacy in fruit fly catches (Epsky et al. 1995, Vargas et al. 1997). Therefore, the objectives of this study were to assess and compare the efficacies of two trap types and two attractants in mass trapping Bactrocera invadens on Mango homestead trees in Ibadan south west Nigeria.

\section{MATERIALS AND METHODS Experimental Site}

The study was carried out in Ibadan, Oyo state South west Nigeria during the mango maturity periods of May- July 2014 and 2015. Ibadan is located within latitude $7^{0}$ and $9^{0} \mathrm{~N}$ longitude $3^{\circ}$ and $58^{\circ} \mathrm{E}$ of green meridian (GMT) with annual rainfall of about $1300 \mathrm{~mm}$ to $1500 \mathrm{~mm}$ and average relative humidity of about 80 to $85 \%$ (FRIN, 2014).

Ibadan has eleven local governments and three local governments were selected as experimental site for the study. They include; Ibadan North West, Iddo, and Akinyele local government areas. Three locations were selected from each local government. The areas selected were known for mango production. Three mango trees were selected in each location with a distance of $10 \mathrm{~m}$ apart.
Collection and Preparation of Brewery Waste

The brewery waste was collected early in the morning from Nigerian brewery Alakia, Ibadan Oyo state, Nigeria when fresh. Twenty kilogram of fresh brewery waste was poured inside an aluminum pot and placed inside another pot contain water. The setup was placed on a gas cooker and boil at for $15 \mathrm{hrs}$ consecutively. It was observe for colour change, when the colour changes from light brown to deep brown the heating was stop, it was allow to cool for $2 \mathrm{hrs}$ and later served with the aid of muslin cloth to collect the solution is known as hydrolyzed crude protein.

\section{Experimental Set-Up}

Two types of Lynfield traps were used; a conventional Lynfield trap (LT) (Figure A) and Modified Lynfield Trap (MLT) (Figure B) made from a recycled transparent 500-ml cylindrical plastic bottle (Eva Water, Nigeria) with two equidistant holes created opposite each other in the uppermost part, a lid and a small metal string which was used as a hanger for one of the attractants. The attractants used were Methyl Eugenol (ME) and Protein bait from Brewery Waste (PBBW). Three trees were selected from each location, the tree within each location were separated by $10 \mathrm{~m}$ to obtain three independent replications within each location. Six traps were randomly hung on each tree. Two hundred and fifty (250) $\mathrm{mls}$ of prepared crude protein and $250 \mathrm{mls}$ methyl eugenol was each baited with $2 \mathrm{mls}$ of cypermethr in (insecticide). The solution was then used to set the trap. Ten (10) mls of baited crude Protein was taken with aid of syringe and carefully dropped on a $0.5 \mathrm{gm}$ of cotton wool and placed at bottom of the trap, the trap was later hung at $1.8 \mathrm{~m}$ above ground level and within the tree canopy. The same procedure was repeated for methyl eugenol. However, $5 \mathrm{mls}$ of methyl eugenol was used while water treatment was used as control. Each treatment was replicated three times per each location. The experiment was set up during the Maturity to ripening stage of mango during the two years when the environmental temperature varied within $27-30^{\circ} \mathrm{C}$ until the fruits were all harvested from the tree.

Catches of $B$ invadens in each trap were counted every week and the attractants in each trap was replaced with new ones weekly for 9 weeks. Data collected were analyzed using ANOVA and the significant means were separated using Turkey's tests.

\section{RESULTS}

Effects of Treatments on Number of B. invadens Trapped on Mango in Ibadan North West (Idishin) The mean density of $B$. invadens flies trapped during the study on mango homestead trees at Ibadan North Local Government is shown in Table 3. The 
results showed significant differences among the treatments during the two seasons of the study. Modified Lynfield trap baited with Methyl eugenol (MLT+ ME) recorded highest population of fruit fly with mean value of 17.63/trap/week, followed by lynfield trap with methyl eugenol (LT+ME) with mean value of $17.41 /$ trap/ week in 2014 . It followed the same trend in 2015 where MLT+ ME recorded highest population of $B$. invadens fly with mean value of 110.80/trap/week, followed by LT+ ME with mean value of $110.58 /$ trap/week. There were no significant differences between the trap types baited with methyl eugnol on the fruit fly density trapped for the two years. The density of $B$. invadens caught in 2015 was significantly ( $\mathrm{p}<$ 0.05 ) higher than that of 2014 in all the trap types and attractants. This indicates population increase with time and suitability of the host plant for their survival and spread. Similarly, there was no significant difference on the density of $B$. invadens caught on Lynfield trap with protein bait from brewery waste (LT + PBBW)) and Modified lynfield trap with protein bait from brewery waste $(\mathrm{MLT}+\mathrm{PBBW})$ for the two years. However, Lynfield tap with protein bait from brewery waste had higher catches of $B$. invadens than modified lynfield trap with protein bait from brewery waste during the two seasons. In 2014, control traps recorded no $B$ invadens in this location while in $2015,0.42 \%$ of B.invadens was trapped.

Effects of Treatments on the Population of $B$. invadens Trapped on Mango in Iddo

The mean population of $B$. invadens flies captured during the study on mango homestead trees at Iddo is shown in Table 3. The results showed that there were significant differences $(\mathrm{p}<0.05)$ among the trap types and attractants on the density of $B$. invadens trapped during the two seasons Modified lynfield trap baited with methyl eugenol (MLT + $\mathrm{ME}$ ) recorded highest catches of $B$. invadens with mean values of 18.41 and 114.62 per trap/week in 2014 and 2015 respectively. This was followed by lynfield trap with methyl eugenol (LT+ME) with mean values of 17.89 and $112 . .10$ in 2014 and 2015 respectively There was no significant difference ( $\mathrm{p}$ $>0.05$ ) between the two trap types for the two seasons Similarly, there was no significant difference on the density of $B$. invadens caught on Lynfield trap with protein bait from brewery waste $(\mathrm{LT}+\mathrm{PBBW})$ and Modified lynfield trap with protein bait from brewery waste (MLT + PBBW) for the two years. However, LT + PBBW recorded higher catches of B. invadens both in 2014 and2015. The population of $B$. invadens trapped in 2015 was significantly higher than 2014 in all the trap types and attractants.
Effects of Treatments on the Population $B$. invadens Trapped on Mango in Akinyele Local Government

The mean numbers of $B$. invadens flies caught during the study on mango homestead trees at Akinyele Local areas is shown in Table 3. The results also showed significant difference ( $\mathrm{p}<$ 0.05 ) among the treatments in both seasons. The densities of $B$. invadens trapped in this location followed the same trend with the other locations. Lynfield trap baited with methyl eugenol (LT+ME) recorded highest population of fruit fly with mean values of 18.19 and 115.55 in 2014 and 2015 respectively. There was significant difference on the densities of flies trapped by the Modified lynfield trap and Lynfield trap with methyl eugenol in 2014 while in 2015 there was no significant difference between the two traps with methyl, however LT + ME caught higher flies. Similarly, there was no significant difference $(p>0.05)$ on population density of fruit fly caught on Lynfield trap baited with Protein bait from brewery waste $(\mathrm{LT}+\mathrm{PBBW})$ and Modified lynfield trap with Protein bait from brewery waste (MLT + PBBW) during the two seasons However, lynfield trap with Protein bait from brewery waste recorded higher $B$. invadens catch than Modified lynfield trap with Protein baith from brewery waste in both seasons.
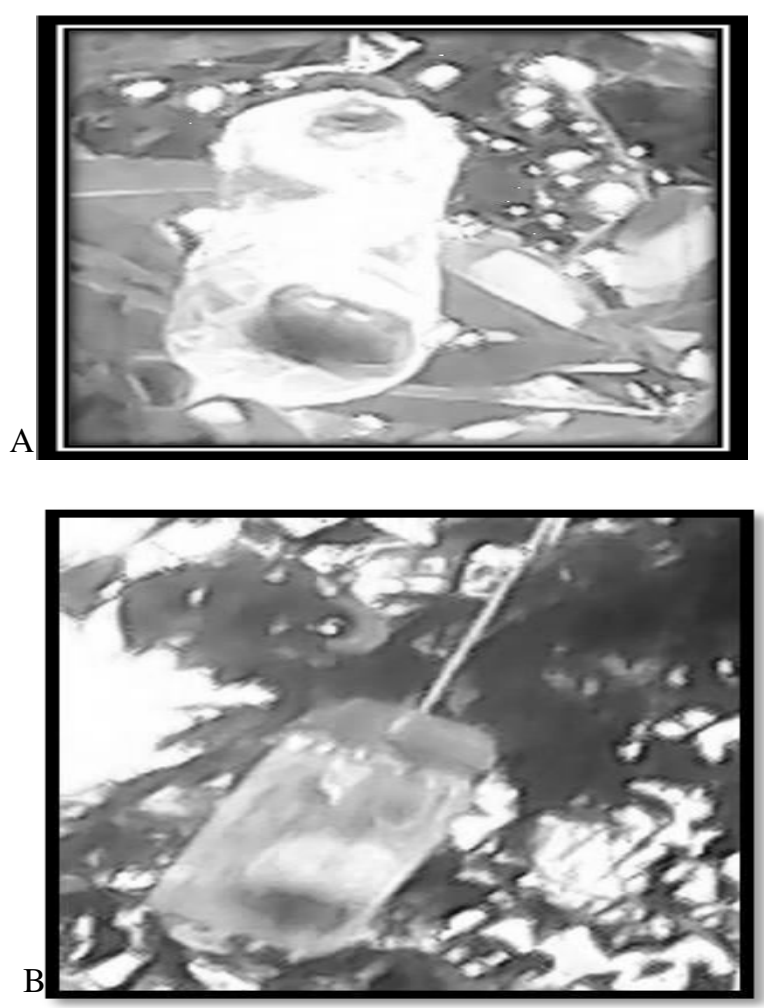

Fig. 1: Lynfield Traps: A - Modified Lynfield Trap (MLT); B Lynfield trap (LT) 
Table 1: Mean population of B. invadens trapped in Ibadan North - West( Idishin)

\begin{tabular}{lcccc}
\hline Treatments & $\begin{array}{c}\text { Mean population/trap/week } \\
\text { in 2014 }\end{array}$ & $\begin{array}{c}\text { Mean population/trap/week } \\
\text { in 2015 }\end{array}$ & $\begin{array}{c}\text { Percentage } \\
\text { population/trap/week } \\
\text { in 2014 }\end{array}$ & $\begin{array}{c}\text { Percentage } \\
\text { population/trap/week } \\
\text { in 2015 }\end{array}$ \\
\hline LT+ME & $17.41 \mathrm{a}$ & $110.58 \mathrm{a}$ & 45.89 & 44.63 \\
LT+PBBW & $1.52 \mathrm{~b}$ & $12.23 \mathrm{~b}$ & 4.01 & 4.94 \\
MLT+ME & $17.63 \mathrm{a}$ & $110.80 \mathrm{a}$ & 46.47 & 44.72 \\
MLT+PBBW & $1.38 \mathrm{~b}$ & $12.09 \mathrm{~b}$ & 3.64 & 4.88 \\
LT+Water & $0.00 \mathrm{~b}$ & $0.33 \mathrm{~b}$ & 0.00 & 0.13 \\
MLT+Water & $0.00 \mathrm{~b}$ & $1.04 \mathrm{~b}$ & 0.00 & 0.42 \\
\hline
\end{tabular}

Means followed by the same letter within the column are not significantly different. LT - Lynfield trap , ME - Methyl eugenol;

PBBW - Protein bait from Brewery Waste; MLT - Modified Lynfield trap

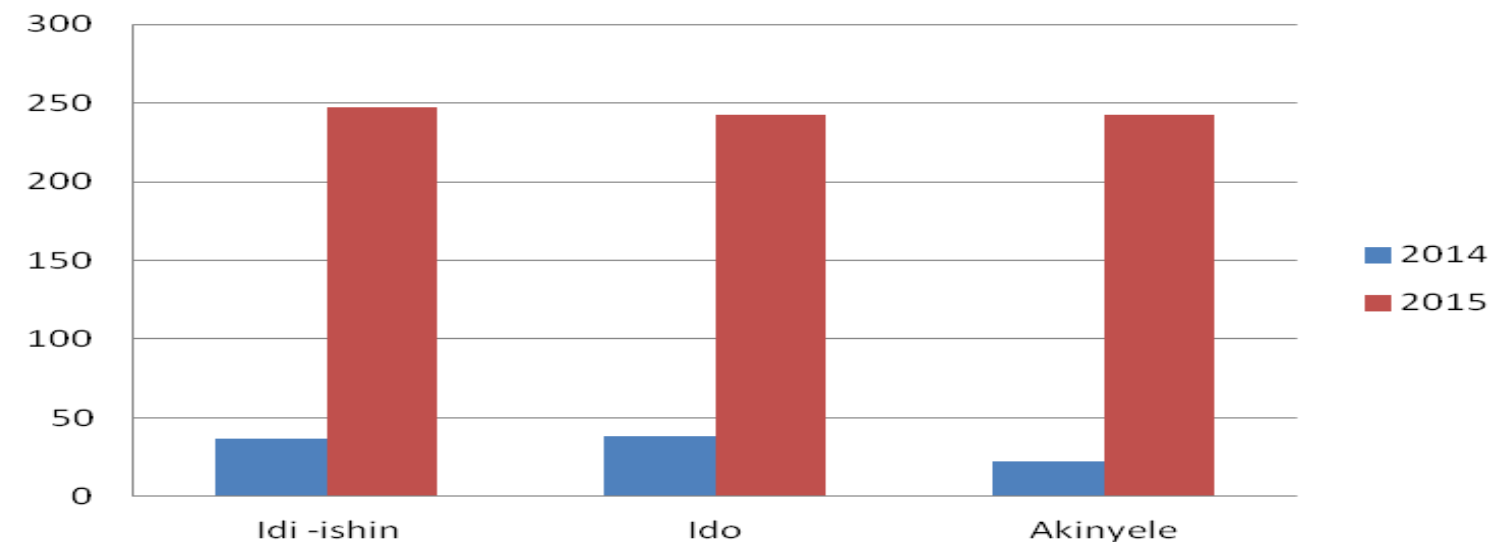

Fig. 2: Mean population of B. invadens trapped on mango in the three villages during the two seasons

Table 2: Mean population of $B$. invadens trapped in Iddo

\begin{tabular}{lcccc}
\hline Treatments & $\begin{array}{c}\text { Mean population/trap/week } \\
\text { in 2014 }\end{array}$ & $\begin{array}{c}\text { Mean population/trap/week } \\
\text { in 2015 }\end{array}$ & $\begin{array}{c}\text { Percentage } \\
\text { population/trap/week } \\
\text { in 2014 }\end{array}$ & $\begin{array}{c}\text { Percentage } \\
\text { population/trap/week } \\
\text { in 2015 }\end{array}$ \\
\hline LT+ME & $17.89 \mathrm{a}$ & $112.10 \mathrm{a}$ & 45.64 & 46.25 \\
LT+PBBW & $1.08 \mathrm{~b}$ & $7.16 \mathrm{~b}$ & 2.76 & 2.95 \\
MLT+ME & $18.41 \mathrm{a}$ & $114.62 \mathrm{a}$ & 46.96 & 47.29 \\
MLT+PBBW & $1.08 \mathrm{~b}$ & $7.90 \mathrm{~b}$ & 4.64 & 3.26 \\
LT+Water & $0.00 \mathrm{~b}$ & $0.27 \mathrm{c}$ & 0.00 & 0.11 \\
MLT+Water & $0.00 \mathrm{~b}$ & $0.33 \mathrm{c}$ & 0.00 & 0.13 \\
\hline
\end{tabular}

Means followed by the same letter within the column are not significantly different. LT - Lynfield trap , ME - Methyl eugenol;

PBBW - Protein bait from Brewery Waste; MLT - Modified Lynfield trap

Table 3: Mean population of B. invadens trapped in Akinyele

\begin{tabular}{lcccc}
\hline Treatments & $\begin{array}{c}\text { Mean population/trap/week } \\
\text { in 2014 }\end{array}$ & $\begin{array}{c}\text { Mean population/trap/week } \\
\text { in 2015 }\end{array}$ & $\begin{array}{c}\text { Percentage } \\
\text { population/trap/week } \\
\text { in 2014 }\end{array}$ & $\begin{array}{c}\text { Percentage } \\
\text { population/trap/week } \\
\text { in 2015 }\end{array}$ \\
\hline LT+ME & $18.19 \mathrm{a}$ & $115.55 \mathrm{a}$ & 52.63 & 47.65 \\
LT+PBBW & $2.52 \mathrm{c}$ & $8.69 \mathrm{~b}$ & $7.29 \mathrm{c}$ & 3.38 \\
MLT+ME & $12.4 \mathrm{~b}$ & $109.76 \mathrm{a}$ & 35.87 & 45.26 \\
MLT+PBBW & $1.45 \mathrm{c}$ & $7.62 \mathrm{~b}$ & 4.20 & 3.14 \\
LT+Water & $0.00 \mathrm{c}$ & $0.41 \mathrm{c}$ & 0.00 & 0.17 \\
MLT+Water & $0.00 \mathrm{c}$ & $0.47 \mathrm{c}$ & 0.00 & 0.19 \\
\hline
\end{tabular}

Means followed by the same letter within the column are not significantly different. LT - Lynfield trap , ME - Methyl eugenol;

PBB - Protein bait from Brewery Waste; MLT - Modified Lynfield trap

The control trapped no fly in 2014 but caught the lowest density of B. invadens in 2015 with $0.17 \%$ and $0.19 \%$ for Lynfield trap and Modified Lynfield trap respectively.

Mean Population of $B$. invadens Trapped on Mango in the Three Villages in the Two Seasons Bacterocera invadens were trapped in all the three villages selected for the study (Fig. 2). There were no significant differences $(\mathrm{p}<0.05)$ on the population density of $B$. invadens trapped in all the location during each season; however, the population of flies trapped in 2015 were significantly higher than 2014 in all the location. The highest number of flies was trapped in Ido in 2014 while in 2015 highest catch of $B$. invadens was in Idi-ishin while the least population were recorded in Akinyele both in 2014 and 2015. 


\section{DISCUSSION}

Traps and attractants evaluated demonstrated their potentials in trapping $B$. invadens on mango homested trees in Ibadan south west Nigeria. Methyl eigenol showed a very high efficacy in masstraping $B$. invadens with different trap types on mango in all the locations of the study. This report corroborates the earlier report that the para-pheromone methyl eugenol (ME) captures a large number of Bactrocera species including: Oriental fruit fly ( $B$. dorsalis), peach fruit fly (B. zonata), carambola fruit fly $(B$. carambolae), Philippine fruit fly (B. philippinensis), and banana fruit fly (B. musae) (IAEA, 2003). Furthermore the findings by Ishaq et al. (2004), Stonehouse et al. (2005) and Jiji et al. (2009) revealed that Methy eugenol is very effective in mass trapping Bactrocera species in mango, stating that that among the various fruit fly management strategies tested ME trap + Bait was the most effective technique. Similarly AFF (2012) stated that Methyl eugenol is the attractant recommended for survey of male Bactrocera invadens and other invasive Bactrocera species such as Bactrocera dorsalis and Bactrocera zonata. Methyl eugenol attracted only male $B$. invadens in all the locations of the study. This report corroborates the earlier report by Russell (1999) that Parapheromone lures (methyl) eugenol, cue-lure, ceralure, trimed lure and latilure attract only males and every fruit fly species in Hawaii is attracted to a different kind.

Correspondingly, Ekesi et al. (2014) reported that Methyl eugenol is a male annihilation lure for $B$. invadens and it attract only males Protein bait of brewery waste trapped both male and female $B$. invadens and other insect species in all the location of the study. This confirms report by Sabine (1992) who reported that Protein baits attract both male and female fruit flies, making them more effective than the male attractant method for field pest management. There were no significant differences $(p<0.05)$ on the density of flies trapped using the same attractant with same trap type in all the locations of the study, although Modified Lynfied trap with same attractants trapped higher flies in two locations than the Lynfield traps. This implies that trap types is a determinant factors of fruit fly trapping efficiency for control programme. This assumption supports Epsky et al. (1995) and Vargas et al. (1997) who reported that traps designs, including different colours and shapes, are essential to obtain a high efficacy in fruit fly catches. Likewise several authors have reported that Tephritid traps vary in effectiveness depending on their size, color, shape and the particular olfactory attractant used (Prokopy, 1969; Prokopy and Bush, 1973; Moericke, 1976; Prokopy and Economopoulos, 1976; Aliniazee and Brown, 1977; Prokopy, 1977; Cytrynowicz et al., 1982; Robacker et al., 1990; Sivinski, 1990). The highest/peak population of $B$. invadens flies were trapped during the fruit ripening period which was in the month of May - June in all the locations of the study during the two seasons. The study by Lutap et al. (2009) also revealed a peak population of fruit flies during May - June, when monitored using ME trap in mango orchard.

\section{CONCLUSION}

All the location recorded incidence of Bactrocera invadens on mango homestead tree in Ibadan south west Nigeria. .Modified lynfield trap with Methyl eugenol was effective in trapping $B$. invadens in the study sites and the highest density of flies were trapped during the peak of mango ripening for the two seasons of the study. Suitable choice of trap and attractants enhances the mass trapping results. The use of locally made Protein bait from brewery waste shows great promise in trapping $B$. invadens on mango. Hence fruit fly traps can be easily improvised and adopted by farmers for fruit fly control while further studies are required on the protein bait brewery waste to enhance their efficacy in mass trapping since they attract both sexes, readily available and less cost effective than paraperomones which attracts only male flies.

\section{REFERENCES}

Aiyelagbe I.O.O., Kintomo A.A., Alasiri K.O. et al. (1999). Citrus production in Nigeria: a state of the art. Res. Monogr. No. 1, NIHORT, Ibadan, Nigeria, 1999

Aliniazee M.T. and Brown R.D. (1977). Laboratory rearing of the western cherry fruit By, Rhagoletis indifferens (Diptera: Tephritidae): oviposition and larval diets. Can. Entomol., 109, 1227-1234

Asawalam E.F. and Nwachukwu J.C. (2011). Incidence of Bactrocera invadens (Drew, Tsuruta \& White) [Diptera: Tephritidae] infestations on mango (Mangifera indica) trees in Abia State Nigeria. $J$. Sustainable Agric. and the Environ., 13 (1), 61-64

AFF (2012). Trapping guidelines surveillance of Bactrocera invadens in fruit production areas. A publ. of Department of Agriculture, Forestry \& Fisheries

Bjeliš M. (2006). Suzbijanje maslinine muhe Bactrocera oleae Gmel. (Diptera, Tephritidae) metodom masovno lova. Fragmenta Phytomedica et Herbologica, 29 (1-2), 35-48

Barcley H.J. and Haniotakis G.E. (1991). Combining pheromone-baited and food- baited traps for insect pest control: effects of developmental period. researches on population. Ecology, 33 (2), 269-285

Broumas T. and Haniotakis I.G. (1987). Further studies on the control of the olive fruit fly by mass trapping. Proc. II International Symposium on fruit flies, Crete, Sept. 1986, pp. 561-565

Broumas T., Haniotakis G., Liaropoulos C., Tomazou T. and Ragousis N. (1998). Effect of attractant, trap density and deployment on the efficacy of the mass trapping method against the olive fruit fly, Bactrocera oleae (Diptera: Tephritidae). Annales de l'Institut Phytopathologique Benaki, 18, 67-80

CABI/EPPO (2008). Bactrocera invadens: Distribution Maps of Plant Pests, No. 709, Edition 2. Wallingford, UK: CAB International.

Cytrynowicz M., Morgante J.S, and de Souza H.M.L. (1982). Visual responses of South American fruit flies, Anastrepha fraterculus, and Mediterranean fruit Bies, Ceratitis capitata, to colored rectangles and spheres. Environ. Entomol. 11, 1202-1210 
Drew R.A.I., Tsuruta K. and White I.M. (2005). A new species of pest fruit fly (Diptera: Tephritidae: Dacinae) from Sri Lanka and Africa. Afr. Entomol. 13, 149-154

Delrio G.I. and Lentini A. (1993). Applicazione della tecnica delle catture massali contro il Dacus oleae in due comprensori olivicoli della Sardegna.-Atti del Convegno "Lotta Integrata in olivicultura" (Progetto Finalizzato MAF "Lotta biologica ed integrate"), Firenze, 21/11/1991, pp. 93-99

Ekesi S., Nderitu P.W. and Rwomushana I. (2006). Field infestation, life history and demographic parameters of Bactrocera invadens Drew, Tsuruta \& White, a new invasive fruit By species in Africa. Bull. Entomol. Res. 96, 379-386

Ekesi S. and Billah M.K. (2007). A field guide to the management of economically important tephritid fruit flies in Africa. ICIPE Science Press, Nairobi, Kenya

Ekesi S., Mohamed S., and Tanga C. (2014). Comparison of food-based attractants for Bactrocera invadens (Diptera: Tephritidae) and evaluation of MazofermSpinosad bait spray for field suppression in mango. Journal of Economic Entomology, 107 (1), 299-309

EPPO (2014). PQR database. Paris, France: European and Mediterranean Plant Protection Organization. http://www.eppo.int/DATABASES/pqr/pqr.htm

Epsky N.D., Heath R.R., Guzman A. and Meyer W.L. (1995). Visual cue and chemical cue interactions in a dry trap with food-based synthetic attractant for Ceratitis capitata and Anastrepha ludens (Diptera: Tephritidae). Environ. Entomol. 24, 1387Đ1395

Evans E.A. (2008). Recent trends in world and U.S. mango production, trade and consumption. Electronic Data Information Source UF/IFAS Extension Publ. \#FE718.008. http://www.edis.ifas.ufl.edu/fe 718

FAOSTAT (2007). FAO Statistics, Food and Agriculture Organization of the United Nations, Rome, Italy

FRIN (2014). Forestry Research Institute of Nigeria Annual Bulletin, Ibadan Nigeria. 64 pp.

Haniotakis G.E., Kozyrakis M. and Hardakis I. (1983). Applications of pheromones for the control of the olive fruit fly. In: Proc. Int. Conf. on Integrated Plant Protection (Vol. 4, pp. 164-171), 4-9 Jul. 1983, Budapest, Hungary

IAEA (2003). Trapping guidelines for area-wide fruit fly programmes. Report of Insect Pest Control Section, Int. Atomic Energy Agency Joint FAO/IAEA Division of Nuclear Techniques in Food and Agriculture. $47 \mathrm{pp}$.

ICIPE (2007). Development and implementation of a sustainable IPM program for major mango pests and opportunity for improving market information and processing in sub-Saharan Africa. http://www.gtz.de./ de/dokumente/en-ICIPEproject1-2007.html

Ishaq M., Usman M., Asif M. and Khan A. (2004). Integrated pest management of mango against mealy bug and fruit fly. Int. J. Agric. Biol., 6, 452-454

Jiji T., Suja G and Verghese A. (2009). Methyl Eugenol traps for the management of fruit fly Bactrocera dorsalis Hendel in Mango. Proc. of the 21st Kerala Science Congress, 28-31 Jan. 2009 pp. 76-77

Lutap L.A., Barroga S.F. and Atis M.I. (2009). Mango fruit fly: Population fluctuation and effectiveness of bait trap for its control. Ilocos Agriculture and Resources Research and Development Consortium

Moericke V. (1976). Response to colour stimuli (in Tephritidae), pp. 23-27. In: Delucchi V.L. (ed.), Studies in Biological Control. Cambridge University Press, Cambridge, United Kingdom
Moreno D., Martinez A.J. and Riviello M.S. (1994). Cyromazine effects on the reproduction of Anastrepha (Diptera: Tephritidae) in the laboratory and in the field. J. Economic Entomol., 87 (1), 202-211

Prokopy R.J. (1969). Visual responses of European cherry fruit flies, Rhagoletis cerasi L. (Diptera: Tephritidae). Polskie Pismo Entomol., 39, 539-566

Prokopy R.J. and Economopoulos A.P. (1976). Color responses of Ceratitis capitata flies. Z. Angew. Entomol., 80, 434-437

Prokopy R.J. and Bush G.L. (1973). Ovipositional responses to different sizes of artipcial fruit by flies of Rhagoletispomonella species group. Ann. Entomol. Soc. Am., 66, 927-929

Prokopy R.J. (1977). Stimuli inßuencing trophic relations in Tephritidae. In: Labeyrie V. (ed.), Comporement des Insects et Milieu Trophique. Coll. Int. CNRS 265, 305-336

Raga A. and Sato M.E. (2006). Time-mortality for fruit flies (Diptera: Tephritidae) exposed to insecticides in laboratory. Neotropical Entomol., 73 (1), 73-77

Robacker D.C., Moreno D.S. and Wolfenbarger D.A. (1990). Effects of trap color, height and placement around trees on capture of Mexican fruit flies (Diptera: Tephritidae). J. Econ. Entomol., 83, 412-419

Russell M. (1999). Managing Fruit Flies on Farms in Hawaii. Publication of College of Tropical Agriculture and Human Resources, University of Hawaii, Manoa. Website: http://www2.ctahr.hawaii.edu/oc/

Rwomushana I., Ekesi S, Gordon I. and Ogol C.K.P.O. (2008). Host plants and host plant preference studies for Bactrocera invadens (Diptera: Tephritidae ) in Kenya, a new invasive fruit fly species in Africa. Ann. Entomol. Soc. Am., 101, 331-340

Sabine B.N.E. (1992). Pre-harvest control methods. International Training Course Fruit Flies. MARDI, Kuala Lumpur. 4-15 ${ }^{\text {th }}$ May, 1992. 20 pp.

Sivinski J. (1990). Colored spherical traps for capture of Caribbean fruit ßy, Anastrepha suspensa. Fla. Entomol., 73, 123-128

Stonehouse J.M., Verghese A., Mumford J.D. et al. (2005). Research communications and recommendations for the on farm IPM of tephritid fruit flies in India. Pest Manage. in Horticultural Ecosys., 11 (2), 172-180

Vayssières J.F, Sinzogan A. and Bokonon-Ganta A. (2008). IITA-CIRAD Regional Control Fruit Fly Project in West Africa. Leaflet No. 2. The new invasive fruit fly species, Bactrocera invadens Drew, Tsuruta \& White. Cotonou \& Montpellier, Benin \& France: IITA \& CIRAD, 4 pp.

Vargas R.I., Prokopy R.J., Duan J.J. Albrecht C. and Li Q.X. (1997). Captures of wild Mediterranean and oriental fruit flies (Diptera: Tephritidae) in Jackson and McPhail traps baited with coffee juice. J. Econ. Entomol. 90, 165-169

Umeh V.C., Fatokun H.K. and Onukwu D. (2002). Insect pests associated with the damage of Chrysophylum albidum G. Don fruits - a case study of Ibadan and its environs. In: Umeh V.C. \& Fagbayide J.A. Proc. $20^{\text {th }}$ Annu. Conf. Hort. Soc. Nigeria (HORTSON), 14-17 May 2002, Natl. Hort. Res. Inst. Audit. Idi-Ishin, Jericho Reservation Area, Ibadan, Nigeria, 257 pp.

Umeh V.C., Garcia L.E. and Meyer M. (2008). Fruit flies of sweet oranges in Nigeria: species diversity, relative abundance and spread in major producing areas. Fruits (Paris), 63 (3), 145-153 